\title{
Benign adult familial myoclonic epilepsy
}

INSERM

\section{Source}

INSERM. (1999). Orphanet: an online rare disease and orphan drug data base. Benign adult familial myoclonic epilepsy. ORPHA:86814

Benign adult familial myoclonic epilepsy (BAFME) is an inherited epileptic syndrome characterized by cortical hand tremors, myoclonic jerks and occasional generalized or focal seizures with a non-progressive or very slowly progressive disease course, and no signs of early dementia or cerebellar ataxia. 